\title{
Scientific Mapping of Industry 4.0 Research: A Bibliometric Analysis
}

\author{
https://doi.org/10.3991/ijim.v15i18.25535 \\ Huma Sikandar ${ }^{1}$, Yamunah Vaicondam ${ }^{2}$, Nohman $\mathrm{Khan}^{3(\mathbb{\varpi})}$, \\ Muhammad Imran Qureshi ${ }^{4}$, Abrar Ullah $^{5}$ \\ ${ }^{1}$ Universiti Teknologi Malaysia (UTM), Johor, Malaysia \\ ${ }^{2}$ SEGi University, Selangor, Malaysia \\ ${ }^{3}$ The Association of Professional Researchers \& Academicians (APRA), Southport, UK \\ ${ }^{4}$ Universiti Teknikal Malaysia, Melaka, Malaysia \\ ${ }^{5}$ University of Swabi, Swabi, Pakistan \\ info@theapra.org
}

\begin{abstract}
The fourth industrial revolution is progressing very rapidly. This research aims to investigate the research patterns and trends of industry 4.0 research with a focus on manufacturing. This bibliometric analysis is performed on data of the past five years (2016 to 2020) retrieved from the Scopus database. This research is conducted on 1426 articles in which the top productive countries, authors, institutions, and most cited articles were investigated. Findings demonstrated that Italy, the United States, and China are the most active countries in terms of research publications. South China University of Technology (China) has been identified as the most productive institution. Wan, J., Li, D., Rauch, E. were found to be the most productive authors. Industry 4.0 is primarily focused on the fields of engineering and computer science and sustainability is the most prolific journal. Co-occurrence analysis of keywords, co-authorship analysis of authors and countries were carried out along with bibliographic coupling of documents using VoS viewer which is the most common information visualisation software. This article summarises the growth of Industry 4.0 in the past five years and gives a short overview of the related works and applications of Industry 4.0.
\end{abstract}

Keywords-Industry 4.0, manufacturing, bibliometric analysis, scopus

\section{Introduction}

The fourth industrial revolution, also known as industry 4.0 refers to current and upcoming changes in the manufacturing industry. It refers to future industry development trends aiming at improving manufacturing processes [1]. With the advent of Industry 4.0, intelligent engineering and digital integration have brought about an overall transformation in futuristic technology [2]. 
The fourth industrial revolution is advancing at a tremendous pace. The first industrial revolution, which used steam as a source of power in the eighteenth century, brought about significant changes in industries. During the second industrial revolution, electric supply and the assembly line were used to mass-produce goods. The third industrial revolution saw the incorporation of information technology and computers into the industry. The fourth industrial revolution is now on the horizon, and it is expected to usher us into the next level of manufacturing by redefining how machines communicate and perform distinct functions. Industry 4.0 is the result of developments in ICT being implemented in the industry [3], [4]. The notion of Industry 4.0 refers to the emergence of new value chains, modifications in business models, and reformation of work processes and service offerings [5-8]. Figure 1 displays the transformation that takes place

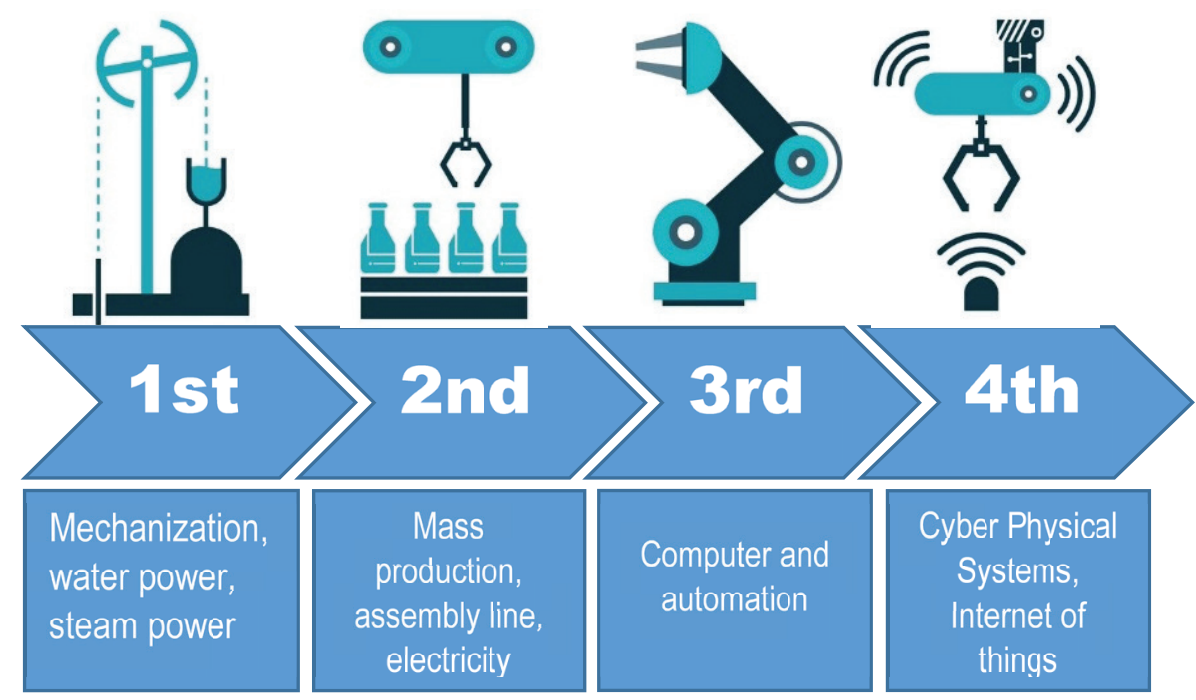

Fig. 1. Evolution of the industrial revolution

Kagermann et al., [9] coined the term "Industry 4.0," which combines the real and virtual worlds with an emphasis on engineering applications. Industry 4.0 is about the complete transformation through intelligent engineering and digital integration. It is about advanced manufacturing in which machine will transform themselves and change the way they communicate and perform functions. For any system to be regarded as industry 4.0, Human support, continuous connectivity and decentralised decision making are unconditional requirements [2]. Cyber-physical systems, additive manufacturing, big data analytics, cloud computing, virtual and augmented reality, data science are some essential components of industry 4.0. Industrial revolution 4.0 is becoming popular among academicians and practitioners due to manufacturing system innovation [10], [11].

Science mapping, also known as bibliometric mapping, is a spatial depiction of the relationships between disciplines, domains, specialities, documents, and authors [12]. 
It's been broadly applied in several research fields to highlight and unveil hidden important aspects (documents, authors, institutions, subjects, and so on) [13-16]. It essentially provides a general overview and overall framework of the research topic. In the past several researchers [2], [3], [17-20] carried out the bibliometric analysis to investigate the trends of industry 4.0 research. Liao et al., [21] underwent a systemic literature review to explore the potential aspects of industry 4.0; field-based researchers; the key lines of research and present research and existing industry initiatives. 4.0 fields of application. Another systematic review by Pagliosa et al., [22] investigated the links between Lean Manufacturing and Industry 4.0 technologies. Another bibliometric study was carried out by Muhuri et al., [2] on the current advancements in "Industry 4.0". Similarly, Kipper et al., [18] through bibliometric analysed the themes in Industry 4.0 research. Gajdzik et al., [3] conducted a similar study to obtained results for Sustainable Industry 4.0. In the same vein, Ajdovec et al., [19] linked industry 4.0 and corporate strategy through a bibliographic coupling and co-citation analysis. Bigliardi et al., [20] conducted a bibliometric analysis by reviewing literature relating industry 4.0 applied to the logistic field.

This study aims to perform a bibliometric analysis on the previous scientific literature on industry 4.0 focusing on just the manufacturing field to identify the most prolific authors, keywords, journals, institutes and highly cited articles. This research also identifies the growth of scientific articles published over the past five years along with the top countries contributing to industry 4.0 research. This study is unique because of most of the previous systematic reviews and bibliometric analysis on the data retrieved from the Web of Science but this research has selected the Scopus database to analyze because Scopus is the most comprehensive database of peer-reviewed literature which cover a wide array of subjects areas with comprehensive coverage of global and regional coverage of journal, conference proceedings, and books.

This research aims to make the following contributions to the existing research.

1. A comprehensive bibliometric analysis of "Industry 4.0" was performed utilising one of the most widely used databases (Scopus).

2. The evolution of Industry 4.0 research over the last five years has been documented.

3. We looked at common factors including highly productive journals, institutions, authors, most cited articles, common subject area and most active countries.

4. A representation of the most prevalent keywords and authors in this field, as taken from the Scopus database, is displayed through information visualisation software.

5. Bibliometric coupling of documents is also performed.

The following is how the rest of the article is structured; Section 2 covers the data collection process and methodology. Section 3 includes a detailed and exhaustive descriptive analysis. In section 4 bibliometric analysis is performed by doing co-authorship analysis of countries and authors, co-occurrence of keywords and bibliometric coupling of documents. Section 5 wraps up the paper by summarising the findings and section 6 mention the limitations and directions for future researchers and academicians. 


\section{Methodology}

\subsection{Data source \& search strategy}

Figure 2 describes the search and selection criteria for the bibliometric analysis. The data has been gathered from one of the most widely referred repositories i.e. Scopus. This study aimed to include the studies relating to industry 4.0 with a focus on the manufacturing sector so the search words were "Industry 4.0" and "Manufacturing" to avoid selecting extraneous documents. The search was carried out on June 18, 2021. The total number of extracted documents was 5559, which was reduced to 4695 after confining the articles to the last five years, i.e. 2016-2020. After limiting the document type to "article" and the source type to "journal," the total number of articles was 1517. There were only 1426 documents in English. As a result, we conducted bibliometric analysis on 1426 papers. Figure 2 depicts the article selection process.

\section{SEARCH AND SELECTION PROCESS OF ARTICLES}

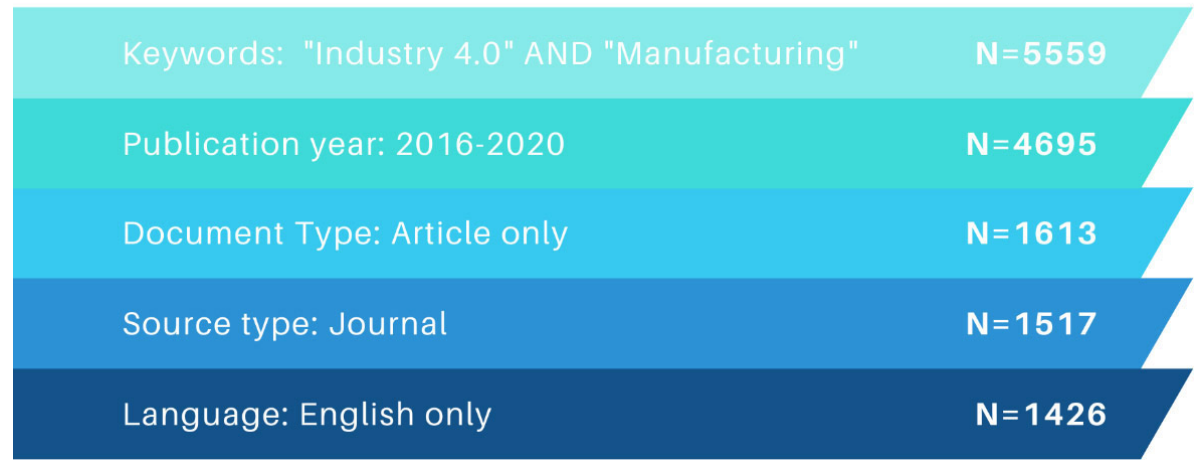

Fig. 2. Article selection process

\section{Descriptive analysis}

\subsection{Publication output}

Figure 3 indicates significant growth in publications of research articles over the last five years, demonstrating the high level of interest developed in the academic community. The growth has rate has increased from 45 documents per year (in 2016) to 603 documents (recorded in 2020). We can see that Industry 4.0 is extremely young from the analyses of publications as only 45 articles were published in 2016. Over a period of only 5 years, the Scopus database has a total of 603 documents. This pattern is anticipated to increase in 2021 and the subsequent years. 


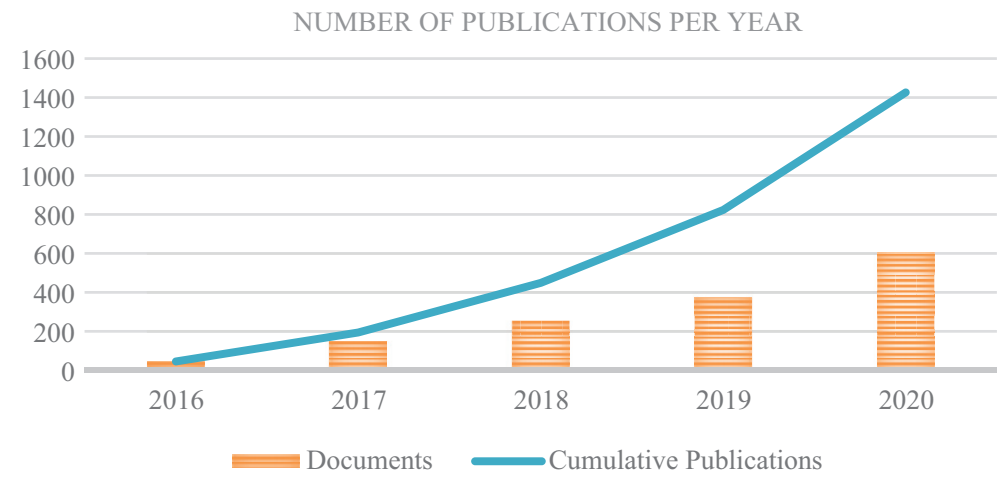

Fig. 3. Publication trend over last 5 years

\subsection{Discipline wise analysis}

Industry 4.0 has been extensively researched in the engineering field, as shown in Figure 4 . The second and thirds most relevant discipline in industry 4.0 in computer science and business and management.

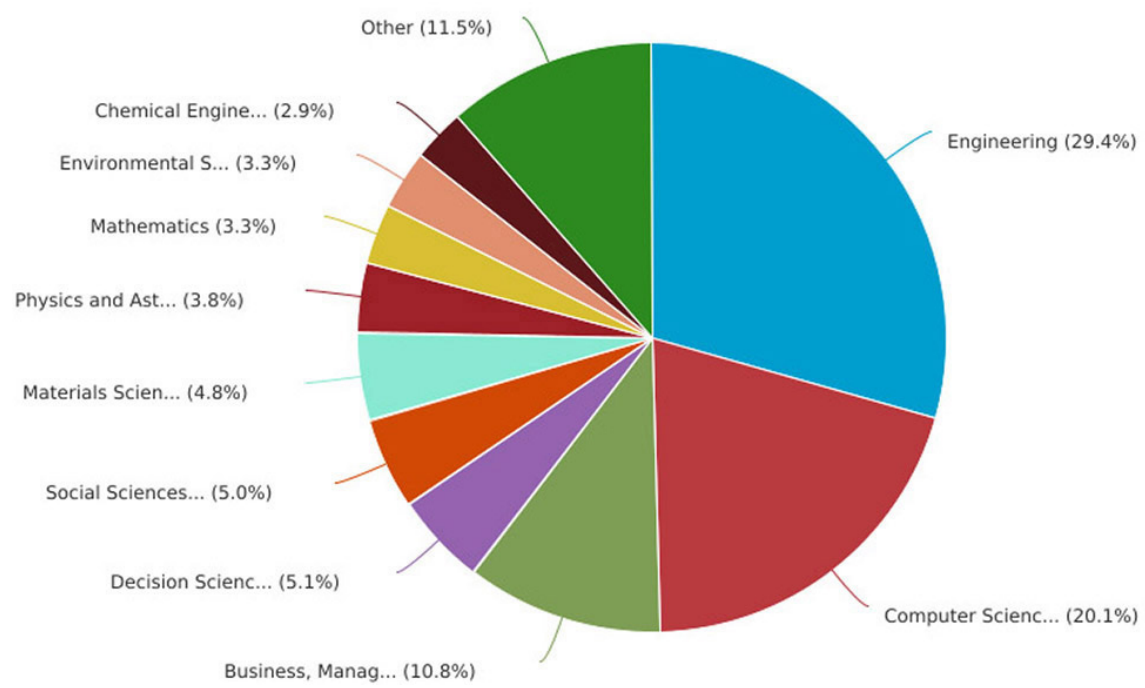

Fig. 4. Documents by subject area

We analysed the leading productive journals and the most mentioned publications in the field of Industry 4.0 research to acquire a better insight. The top five most prolific journals are Sustainability $(\mathrm{TP}=55)$, International Journal of Advanced Manufacturing Technology ( $\mathrm{TP}=50)$, Applied Sciences Switzerland ( $\mathrm{TP}=46)$, IEEE Access $(\mathrm{TP}=46)$ and International Journal of Production Research $(\mathrm{TP}=46)$. The total number of publications in the collected dataset is denoted by the letter TP. Table 1 summarises the top 10 productive journals most cited articles. 
Table 1. Most productive journals most cited articles

\begin{tabular}{|c|c|c|c|c|c|c|c|}
\hline Rank & Journal & TP & $\begin{array}{c}\text { Cite Score } \\
2020\end{array}$ & \begin{tabular}{|c|} 
No. of \\
Citations
\end{tabular} & $\begin{array}{c}\text { The Most Cited } \\
\text { Article }\end{array}$ & $\begin{array}{l}\text { Times } \\
\text { Cited }\end{array}$ & Publisher \\
\hline 1 & $\begin{array}{l}\text { Sustainability } \\
\text { Switzerland }\end{array}$ & $\begin{array}{c}55 \\
(3.86 \%)\end{array}$ & 3.9 & 729 & $\begin{array}{l}\text { What drives the } \\
\text { implementation of } \\
\text { Industry } 4.0 \text { ? The } \\
\text { role of opportunities } \\
\text { and challenges in the } \\
\text { context of sustainability }\end{array}$ & 182 & MDPI AG \\
\hline 2 & $\begin{array}{l}\text { International } \\
\text { Journal of } \\
\text { Advanced } \\
\text { Manufacturing } \\
\text { Technology }\end{array}$ & $\left(\begin{array}{c}50 \\
(3.51 \%)\end{array}\right.$ & 5.6 & 395 & $\begin{array}{l}\text { Evaluating the } \\
\text { effectiveness of spatial } \\
\text { augmented reality in } \\
\text { smart manufacturing: } \\
\text { a solution for manual } \\
\text { working stations }\end{array}$ & 56 & Springer London \\
\hline 3 & $\begin{array}{l}\text { Applied } \\
\text { Sciences } \\
\text { Switzerland }\end{array}$ & $\begin{array}{c}46 \\
(3.23 \%)\end{array}$ & 3 & 186 & $\begin{array}{l}\text { Enabling technologies } \\
\text { for operator } 4.0: \mathrm{A} \\
\text { survey }\end{array}$ & 32 & MDPI AG \\
\hline 4 & IEEE Access & $\begin{array}{c}46 \\
(3.23 \%)\end{array}$ & 4.8 & 1407 & $\begin{array}{l}\text { Digital Twin and Big } \\
\text { Data Towards Smart } \\
\text { Manufacturing and } \\
\text { Industry } 4.0: 360 \\
\text { Degree Comparison }\end{array}$ & 249 & $\begin{array}{l}\text { Institute of } \\
\text { Electrical and } \\
\text { Electronics } \\
\text { Engineers Inc. }\end{array}$ \\
\hline 5 & $\begin{array}{l}\text { International } \\
\text { Journal of } \\
\text { Production } \\
\text { Research }\end{array}$ & $\begin{array}{c}39 \\
(2.73)\end{array}$ & 10.8 & 1956 & $\begin{array}{l}\text { Industry 4.0: State of } \\
\text { the art and future trends }\end{array}$ & 526 & Taylor \& Francis \\
\hline 6 & $\begin{array}{l}\text { Sensors } \\
\text { Switzerland }\end{array}$ & $\begin{array}{c}37 \\
(2.59 \%)\end{array}$ & 5.8 & 157 & $\begin{array}{l}\text { A fog computing based } \\
\text { cyber-physical system } \\
\text { for the automation of } \\
\text { pipe-related tasks in the } \\
\text { industry } 4.0 \text { shipyard }\end{array}$ & 35 & $\begin{array}{l}\text { Multidisciplinary } \\
\text { Digital Publishing } \\
\text { Institute (MDPI) }\end{array}$ \\
\hline 7 & $\begin{array}{l}\text { Computers } \\
\text { And Industrial } \\
\text { Engineering }\end{array}$ & $\begin{array}{c}29 \\
(2.03 \%)\end{array}$ & 7.9 & 484 & $\begin{array}{l}\text { A review of Internet of } \\
\text { Things (IoT) embedded } \\
\text { sustainable supply } \\
\text { chain for industry } 4.0 \\
\text { requirements }\end{array}$ & 87 & Elsevier \\
\hline 8 & $\begin{array}{l}\text { Computers in } \\
\text { Industry }\end{array}$ & $\begin{array}{c}28 \\
(1.96 \%)\end{array}$ & 12 & 953 & $\begin{array}{l}\text { Industry } 4.0 \text { and the } \\
\text { current status as well } \\
\text { as future prospects on } \\
\text { logistics }\end{array}$ & 427 & Elsevier \\
\hline 9 & $\begin{array}{l}\text { International } \\
\text { Journal of } \\
\text { Computer } \\
\text { Integrated } \\
\text { Manufacturing }\end{array}$ & $\begin{array}{c}25 \\
(1.75 \%)\end{array}$ & 6.4 & 268 & $\begin{array}{l}\text { Introduction and } \\
\text { establishment of virtual } \\
\text { training in the factory of } \\
\text { the future }\end{array}$ & 45 & Taylor \& Francis \\
\hline 10 & $\begin{array}{l}\text { Manufacturing } \\
\text { Letters }\end{array}$ & $\begin{array}{c}23 \\
(1.61 \%)\end{array}$ & 5.6 & 463 & $\begin{array}{l}\text { Industrial Artificial } \\
\text { Intelligence for } \\
\text { Industry 4.0-based } \\
\text { manufacturing systems }\end{array}$ & 99 & Elsevier \\
\hline
\end{tabular}


The findings of our analysis revealed the top 10 prolific authors with the most cited scientific publications. Table 2 shows that Wan, J. is the highest-ranked contributor with 18 total publications (TP) and 1926 citations. Li, D. and Rauch, E. are the second and third most productive authors with 17 and 13 total publications (and 1657 and 153 citations) respectively.

Table 2. Top 10 most productive authors

\begin{tabular}{|c|c|c|c|c|c|c|c|c|}
\hline Rank & Author & TP & $\begin{array}{c}\text { Scopus } \\
\text { Author ID }\end{array}$ & $\begin{array}{l}\text { Year of 1st } \\
\text { Publication }\end{array}$ & h-Index & $\begin{array}{c}\text { Current } \\
\text { Affiliation }\end{array}$ & Country & $\begin{array}{c}\text { Total } \\
\text { Citation }\end{array}$ \\
\hline 1 & Wan, J. & 18 & 24333732700 & 2016 & 47 & $\begin{array}{l}\text { South China } \\
\text { University of } \\
\text { Technology }\end{array}$ & China & 1926 \\
\hline 2 & Li, D. & 17 & 35755595200 & 2016 & 30 & $\begin{array}{l}\text { South China } \\
\text { University of } \\
\text { Technology }\end{array}$ & China & 1657 \\
\hline 3 & $\begin{array}{l}\text { Rauch, } \\
\text { E. }\end{array}$ & 13 & 32467549600 & 2017 & 21 & $\begin{array}{l}\text { Free University of } \\
\text { Bozen-Bolzano }\end{array}$ & Italy & 153 \\
\hline 4 & Wang, S. & 12 & 55793953600 & 2016 & 15 & $\begin{array}{l}\text { South China } \\
\text { University of } \\
\text { Technology }\end{array}$ & China & 1494 \\
\hline 5 & $\begin{array}{l}\text { Matt, } \\
\text { D.T. }\end{array}$ & 10 & 23974953600 & 2017 & 20 & $\begin{array}{l}\text { Fraunhofer Italia } \\
\text { Research s.c.a.r.l. }\end{array}$ & Italy & 124 \\
\hline 6 & Wuest, T. & 10 & 57210671396 & 2018 & 18 & $\begin{array}{l}\text { West Virginia } \\
\text { University }\end{array}$ & $\begin{array}{l}\text { United } \\
\text { States }\end{array}$ & 179 \\
\hline 7 & Tao, F. & 9 & 12141248300 & 2017 & 60 & $\begin{array}{l}\text { Beihang } \\
\text { University }\end{array}$ & China & 884 \\
\hline 8 & Liu, C. & 8 & 7409795747 & 2017 & 28 & $\begin{array}{l}\text { Shanghai Jiao } \\
\text { Tong University }\end{array}$ & China & 435 \\
\hline 9 & Wang, L. & 8 & 55080150600 & 2017 & 49 & $\begin{array}{l}\text { The Royal Institute } \\
\text { of Technology } \\
\text { (KTH) }\end{array}$ & Sweden & 212 \\
\hline 10 & $\mathrm{Xu}, \mathrm{X}$. & 8 & 57207454205 & 2017 & 47 & $\begin{array}{l}\text { The University of } \\
\text { Auckland }\end{array}$ & $\begin{array}{l}\text { New } \\
\text { Zealand }\end{array}$ & 964 \\
\hline
\end{tabular}

\subsection{The leading countries and institutions the topmost productive institutions}

While analysing the leading countries we found that Italy (176 publications), the United States (164 publications), and China (147 publications) have been among the top 3 countries in most publications over the last five years. Similarly, the total number of publications and single country publication is shown in Table 4 for the top 10 countries. 


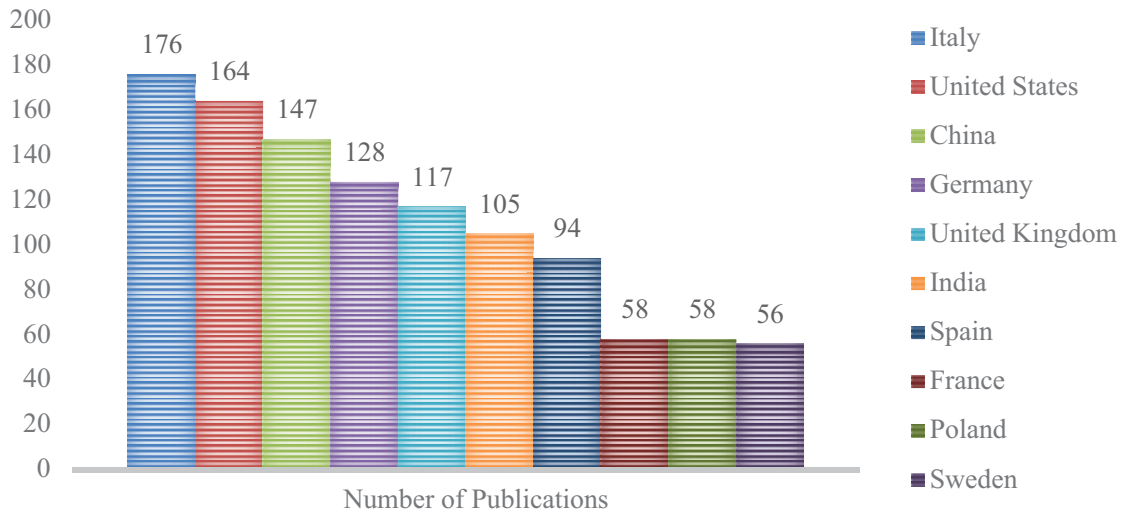

Fig. 5. Top 10 productive countries

As per our investigation of the top ten academic institutions, the South China University of Technology is the most productive in terms of the number of published articles (i.e. 26 publications). With 22 and 19 publications, respectively, the Università Degli Studi di Napoli Federico II and the Free University of Bozen-Bolzano came in second and third place. Table 3 lists the institutions that rank in the top ten in our analysis.

Table 3. The top 10 most productive institutions

\begin{tabular}{|l|l|l|c|}
\hline \multicolumn{1}{|c|}{ Rank } & \multicolumn{1}{c|}{ Institution } & \multicolumn{1}{c|}{ Country } & No. of Publications \\
\hline 1 & South China University of Technology & China & 26 \\
\hline 2 & Università degli Studi di Napoli Federico II & Italy & 22 \\
\hline 3 & Free University of Bozen-Bolzano & Italy & 19 \\
\hline 4 & Shanghai Jiao Tong University & China & 18 \\
\hline 5 & Politecnico di Milano & Italy & 17 \\
\hline 6 & Universidad del Pais Vasco & Spain & 17 \\
\hline 7 & Tecnologico de Monterrey & Mexico & 16 \\
\hline 8 & Beihang University & China & 16 \\
\hline 9 & Università degli Studi di Padova & Italy & 15 \\
\hline 10 & King Saud University & Saudi Arabia & 15 \\
\hline
\end{tabular}

\subsection{Bibliometric analysis}

This section describes the bibliometric analysis of co-authorship of countries, co-occurrence of author keywords, co-authorship of authors and the bibliographic coupling. In bibliographic coupling, the total link strength (TLS) indicates the commonly cited references that two publication have. In the case of co-authorship analysis, it shows the number of co-authored publications of two researchers and in the case of co-occurrence TLS point to the number of publications in which any two terms appear together [23]. 


\subsection{Co-authorship of countries}

For the co-authorship of countries analysis which shows the collaboration of authors from different geographical locations, the minimum number of countries were set to 5 (meaning a minimum of 5 published documents per country). As a result out of 80 countries, 51 met the threshold. In figure two nearly located countries mean the strong affiliation that they have with each other.

Through the co-authorship analysis, we discovered that the United States has the most affiliations with other countries, with 38 linkages and a total link strength of 137, while it has 164 published articles and 4764 citations. It was followed by UK (links: 37, TLS: 116, documents: 117 and citations: 3954) and China (links: 30, TLS: 116, documents: 147 and citations: 5930). The list of all 51 countries with their association strength, number of documents and total citations are listed in Table 4 and a screenshot from the VOS viewer of how the countries are affiliated is shown in Figure 6.

Table 4. Results of co-authorship analysis of countries

\begin{tabular}{|c|c|c|c|c|c|c|c|}
\hline Country & Documents & Citations & \begin{tabular}{|c|} 
Total Link \\
Strength
\end{tabular} & Country & Documents & Citations & $\begin{array}{c}\text { Total Link } \\
\text { Strength }\end{array}$ \\
\hline Australia & 32 & 446 & 37 & Netherlands & 15 & 255 & 20 \\
\hline Austria & 27 & 602 & 22 & New Zealand & 11 & 1257 & 12 \\
\hline Belgium & 10 & 130 & 11 & Norway & 17 & 565 & 14 \\
\hline Brazil & 54 & 2013 & 37 & Pakistan & 8 & 255 & 13 \\
\hline Canada & 32 & 837 & 33 & Philippines & 5 & 33 & 8 \\
\hline Chile & 5 & 177 & 6 & Poland & 58 & 587 & 30 \\
\hline China & 147 & 5930 & 116 & Portugal & 38 & 809 & 24 \\
\hline Colombia & 14 & 331 & 12 & Romania & 23 & 209 & 21 \\
\hline Croatia & 11 & 162 & 6 & Russian & 21 & 357 & 8 \\
\hline $\begin{array}{l}\text { Czech } \\
\text { Republic }\end{array}$ & 26 & 249 & 25 & Saudi Arabia & 20 & 842 & 27 \\
\hline Denmark & 30 & 450 & 24 & Serbia & 9 & 162 & 6 \\
\hline Finland & 15 & 371 & 18 & Singapore & 16 & 342 & 15 \\
\hline France & 58 & 2378 & 59 & Slovakia & 27 & 268 & 28 \\
\hline Germany & 128 & 4229 & 94 & Slovenia & 14 & 180 & 9 \\
\hline Greece & 20 & 422 & 8 & South Africa & 22 & 336 & 18 \\
\hline Hong Kong & 15 & 531 & 19 & South Korea & 40 & 1007 & 23 \\
\hline Hungary & 25 & 598 & 16 & Spain & 94 & 1634 & 59 \\
\hline India & 106 & 2063 & 57 & Sweden & 56 & 2439 & 55 \\
\hline Indonesia & 9 & 18 & 3 & Switzerland & 16 & 815 & 18 \\
\hline Iran & 11 & 409 & 14 & Taiwan & 53 & 991 & 14 \\
\hline Ireland & 14 & 358 & 24 & Thailand & 10 & 81 & 3 \\
\hline Italy & 176 & 3446 & 75 & Turkey & 19 & 363 & 5 \\
\hline Japan & 15 & 315 & 11 & United Kingdom & 117 & 3954 & 116 \\
\hline Malaysia & 41 & 347 & 36 & United States & 164 & 4748 & 137 \\
\hline Mexico & 24 & 351 & 18 & Viet Nam & 5 & 39 & 10 \\
\hline Morocco & 9 & 15 & 4 & & & & \\
\hline
\end{tabular}




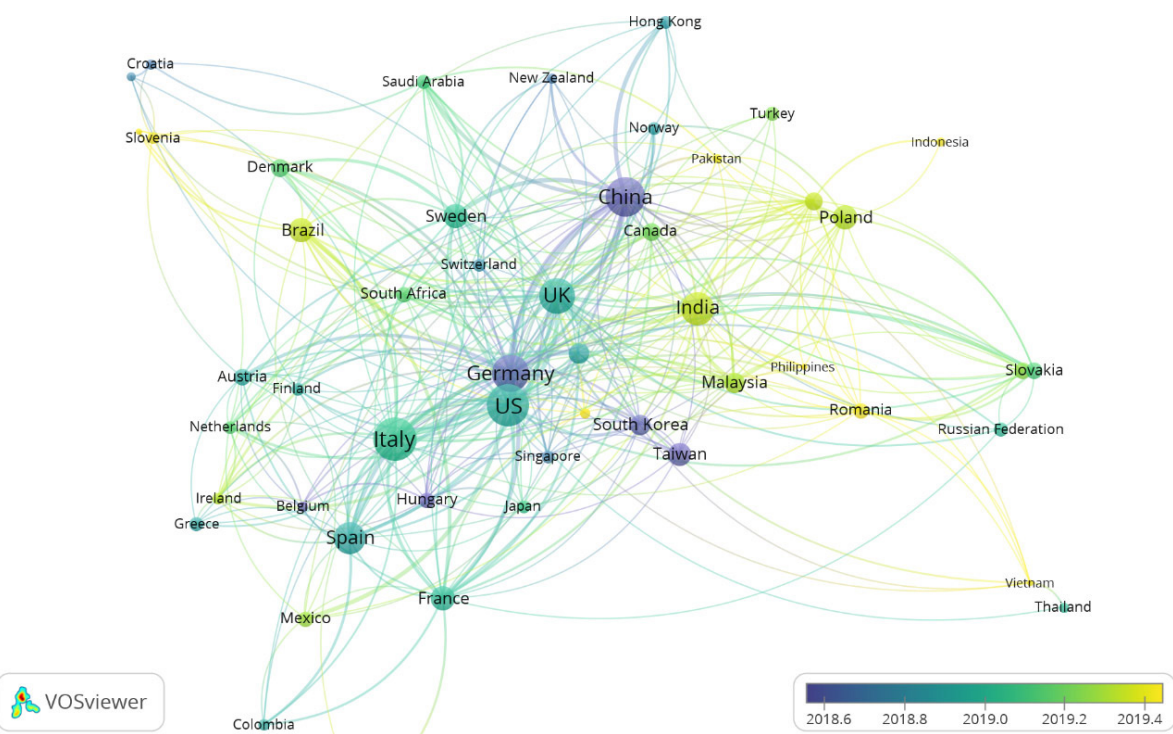

Fig. 6. Snapshot of the bibliometric map representing co-authorship analysis of countries in overlay visualisation mode

Scientific collaboration is thought to be a vital component of improving the quality and impact of research [24]. There is a range of approaches to boost international collaboration, including expanding the number of visiting researchers, forming a variety of alliances, and allocating massive research funds. To improve international linkages, a stable and adaptable research policy is required [25].

\subsection{Co-authorship (authors)}

In this, a co-authorship analysis of authors is done to identify the collaborated network and authors who contributed to the field by working together. co-authorship analysis is the main research methods to study research collaboration (RC) [26]. The links indicate the researcher's total number of co-authorship links with other researchers. The Total link strength (TLS) indicates the total strength of a researcher's co-authorship links with other researchers [23].

For co-authorship analysis of authors, the threshold for a minimum number of authors was set to 5 and a minimum number of citations of an author to 10 . Out of 4020 authors, 50 authors met the threshold. Out of these 50 authors, 22 authors were well connected forming 4 clusters (as displayed in Figure 7). This represents stat these 22 authors are well connected and has contributed to the literature by working together. 


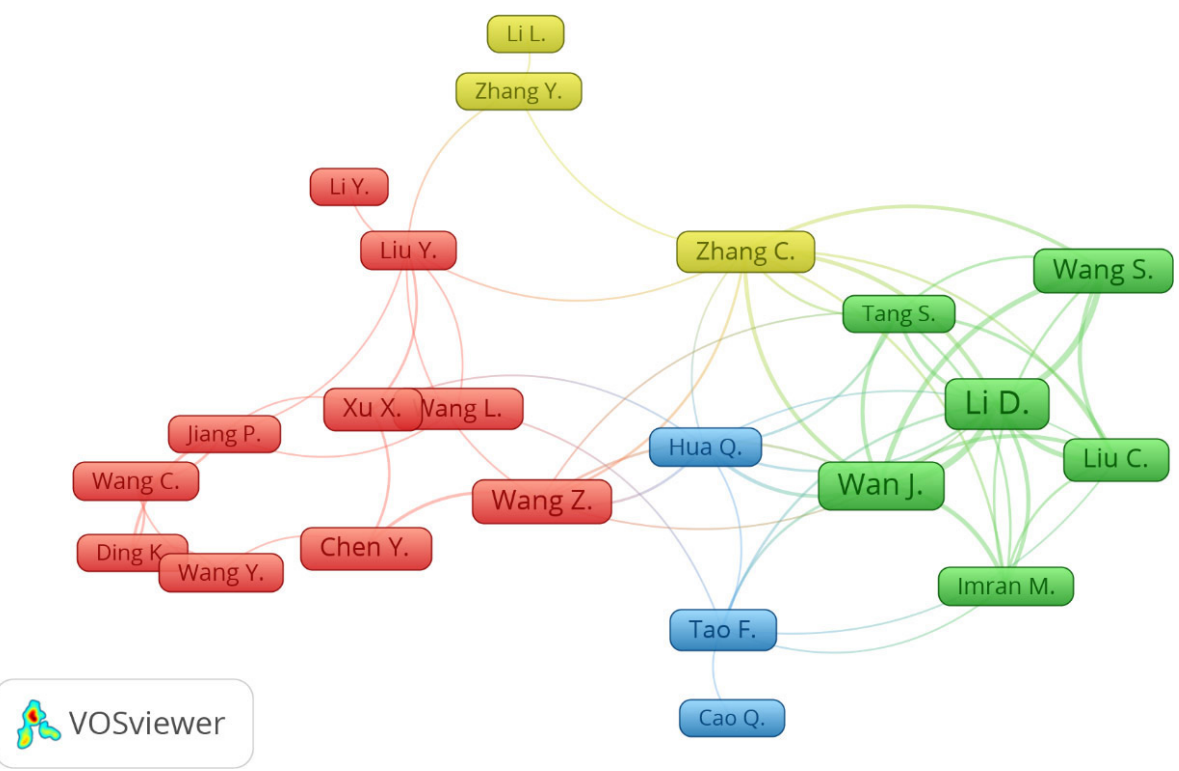

Fig. 7. Snapshot of the bibliometric map representing co-authorship analysis of authors in network visualisation mode

It was found that $\mathrm{Li} \mathrm{D}$. has the highest total link strength (TLS=52) with 24 published documents and 2240 citations, followed by Wan J. (TLS=50, documents $=18$ and citations $=2322$ ) and Wang S. (TLS=33, documents $=12$ and citations $=1758)$. Similarly, the links, TLS, documents and citations for all of the 22 authors are shown in Table 5.

Table 5. Co-authorship analysis of authors

\begin{tabular}{|l|c|c|c|c|}
\hline \multicolumn{1}{|c|}{ Authors } & No. of Links & Total Link Strength & Documents & Citations \\
\hline Li D. & 9 & 52 & 24 & 2240 \\
\hline Wan J. & 9 & 50 & 18 & 2322 \\
\hline Wang S. & 6 & 33 & 12 & 1758 \\
\hline Liu C. & 8 & 27 & 10 & 583 \\
\hline Zhang C. & 10 & 25 & 9 & 832 \\
\hline Tang S. & 8 & 21 & 5 & 714 \\
\hline Imran M. & 7 & 20 & 6 & 569 \\
\hline Hua Q. & 8 & 14 & 6 & 236 \\
\hline Wang Z. & 7 & 12 & 13 & 138 \\
\hline Tao F. & 7 & 9 & 9 & 1206 \\
\hline
\end{tabular}

(Continued) 
Table 5. Co-authorship analysis of authors (continued)

\begin{tabular}{|l|c|c|c|c|}
\hline \multicolumn{1}{|c|}{ Authors } & No. of Links & Total Link Strength & Documents & Citations \\
\hline Jiang P. & 5 & 8 & 5 & 99 \\
\hline Liu Y. & 7 & 8 & 7 & 293 \\
\hline Xu X. & 5 & 8 & 11 & 1277 \\
\hline Chen Y. & 3 & 6 & 10 & 120 \\
\hline Ding K. & 3 & 6 & 5 & 78 \\
\hline Wang C. & 3 & 5 & 6 & 86 \\
\hline Wang L. & 4 & 5 & 9 & 312 \\
\hline Wang Y. & 3 & 3 & 6 & 139 \\
\hline Zhang Y. & 3 & 3 & 5 & 35 \\
\hline Cao Q. & 1 & 1 & 5 & 38 \\
\hline Li L. & 1 & 1 & 5 & 981 \\
\hline Li Y. & 1 & 1 & 5 & 143 \\
\hline
\end{tabular}

\subsection{Co-occurrence author keywords}

The different sections of articles stored in scientific databases are important, so is the case with author keywords. Co-occurrence refers to the number of occurrences of keywords in a particular document [27], [28]. The number of times a word appears in a document is represented by the total link strength. The size of nodes can indicate the frequency of keywords: the larger the node, the higher the frequency of the keyword. The thickness of the line is related to the proximity of two keywords; the thicker the line between two words, the closer the association.

In keyword analysis, when importing Scopus data to VOS viewer, the minimum number of keyword occurrences was set to 5, resulting in the detection of 156 keywords out of 3757 . Then the identical keywords were replaced, resulting in 3716 keywords out of which 111 met the criteria. In other words, only 111 keywords met the threshold level of 5 occurrences per keyword. The number of occurrences of a single keyword was set to 5 as previously mentioned which resulted in 9 different clusters of keywords.

Some of the identified keywords with top occurrences are Cyber-Physical system, the Internet of Things, smart manufacturing, smart factories, manufacturing, big data, digitalisation, sustainable manufacturing, additive manufacturing, digital twins, machine learning, artificial intelligence and cloud computing.

On the contrary, some of the articles with the least number of occurrence are design, human factors, artificial neural networks, critical success factors, data science, anomaly detection, customization, human-robot collaboration, $5 \mathrm{~g}$, business process management, neural networks, remanufacturing, decision making, quality, skills, decisional DNA, emerging economies, collaborative manufacturing and process mining. Through this analysis, we can infer that in the above-mentioned area more research is required to gain more understanding of the concept and extend the literature. 


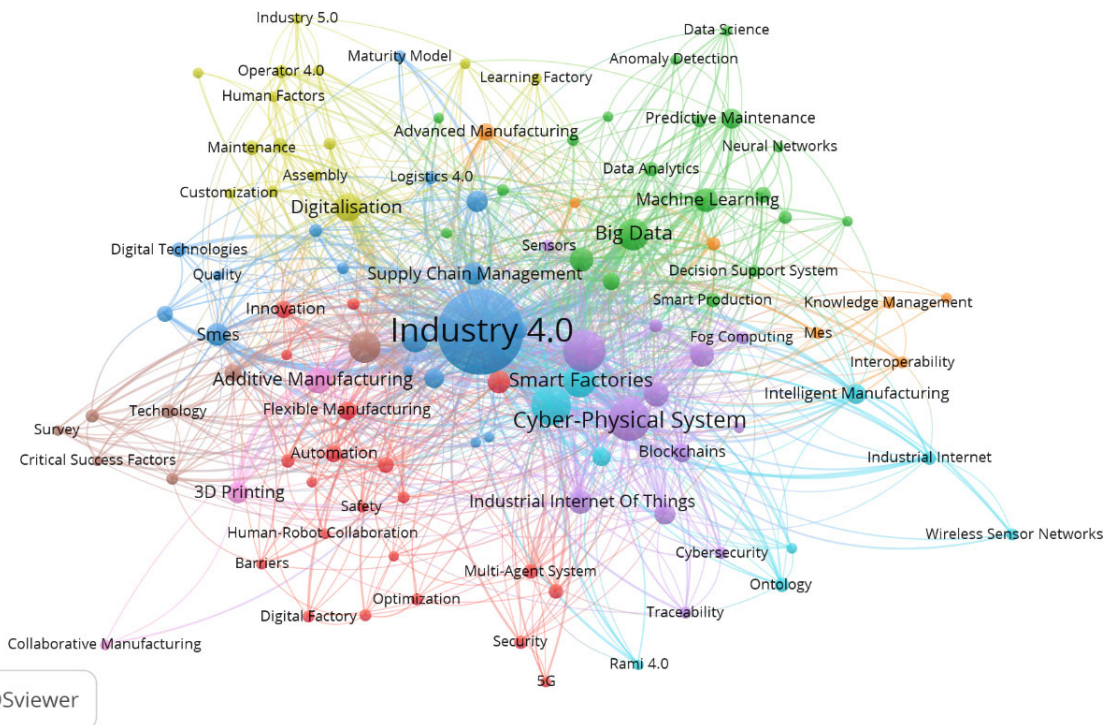

Fig. 8. Snapshot of the bibliometric map representing co-occurrence analysis of keywords in network visualisation mode

The number of links, TLS, citations and occurrences of the top 20 author keywords is shown in Table 6.

Table 6. Top 20 author keywords

\begin{tabular}{|l|c|c|c|}
\hline \multicolumn{1}{|c|}{ Keyword } & Links & TLS & Occurrences \\
\hline Industry 4.0 & 110 & 1610 & 971 \\
\hline Cyber-Physical System & 79 & 459 & 168 \\
\hline Internet of Things & 73 & 454 & 169 \\
\hline Smart Manufacturing & 64 & 333 & 144 \\
\hline Smart Factories & 62 & 232 & 92 \\
\hline Big Data & 46 & 224 & 78 \\
\hline Manufacturing & 56 & 194 & 84 \\
\hline Digitalisation & 40 & 142 & 59 \\
\hline Cloud Computing & 34 & 136 & 39 \\
\hline Digital Twins & 41 & 116 & 45 \\
\hline Additive Manufacturing & 31 & 109 & 51 \\
\hline Sustainable Manufacturing & 37 & 109 & 53 \\
\hline Artificial Intelligence & 37 & 99 & 39 \\
\hline Industrial Internet of Things & 34 & 98 & 38 \\
\hline Machine Learning & 33 & 94 & 42 \\
\hline
\end{tabular}

(Continued) 
Table 6. Top 20 author keywords (continued)

\begin{tabular}{|l|c|c|c|}
\hline \multicolumn{1}{|c|}{ Keyword } & Links & TLS & Occurrences \\
\hline Smes & 26 & 85 & 34 \\
\hline Digital Transformation & 27 & 76 & 31 \\
\hline Cloud Manufacturing & 26 & 71 & 31 \\
\hline Blockchains & 27 & 69 & 21 \\
\hline 3D Printing & 20 & 64 & 29 \\
\hline
\end{tabular}

\subsection{Bibliographic coupling (documents)}

Analysis was done in VoSviewer with bibliographical coupling. Bibliographic coupling links papers that cite the same articles and represents the current state-of-the-art of the examined field. Our counting method was full counting, our unit of analysis documented. We have predetermined that the minimum number of citations of a document has to be 10 . Out of the 1426 documents, 596 have met the threshold and for all of those documents, the total strength of the bibliographical coupling links with other documents will be calculated. The largest set of connected items consists of 558 items. Out of 558 items, 13 clusters in total have been formed with 33923 links and 62768 link strength (TLS).

Figures 9 and 10 shows the bibliographic coupling of documents. As shown in the figures, the more bibliographic coupling the larger the size of the circle. It was found that artilce by Manavalan E. published in 2019 has the highest total link strength (TLS) of 1559 with 148 citations. Similarly, the top 20 publications (documents) according to the TLS are listed in Table 7.

Table 7. Bibliographic coupling of documents (top 20) as per TLS

\begin{tabular}{|l|c|c|l|c|c|}
\hline \multicolumn{1}{|c|}{ Document } & Citations & $\begin{array}{c}\text { Total Link } \\
\text { Strength }\end{array}$ & \multicolumn{1}{|c|}{ Document } & Citations & $\begin{array}{c}\text { Total Link } \\
\text { Strength }\end{array}$ \\
\hline Manavalan E. (2019) & 148 & 1559 & Sony M. (2020) & 26 & 903 \\
\hline Fettermann D.C. (2018) & 56 & 1141 & Lusarczyk B. (2019) & 25 & 898 \\
\hline Osterrieder P. (2020) & 44 & 1102 & Kipper L.M. (2020) & 35 & 863 \\
\hline Ghobakhloo M. (2018) & 262 & 1091 & Kamble S. (2020) & 63 & 834 \\
\hline Wang X. (2018) & 40 & 1071 & Xu L.D. (2018) & 714 & 833 \\
\hline Culot G. (2020b) & 49 & 1034 & Kiel D. (2017) & 192 & 829 \\
\hline Mariani M. (2019) & 39 & 968 & Savastano M. (2019) & 31 & 806 \\
\hline Ghobakhloo M. (2020b) & 25 & 966 & Culot G. (2020a) & 24 & 805 \\
\hline Ghobakhloo M. (2019) & 28 & 946 & Tsai W.-H. (2018c) & 24 & 797 \\
\hline Zhong R.Y. (2017a) & 791 & 914 & & & \\
\hline
\end{tabular}




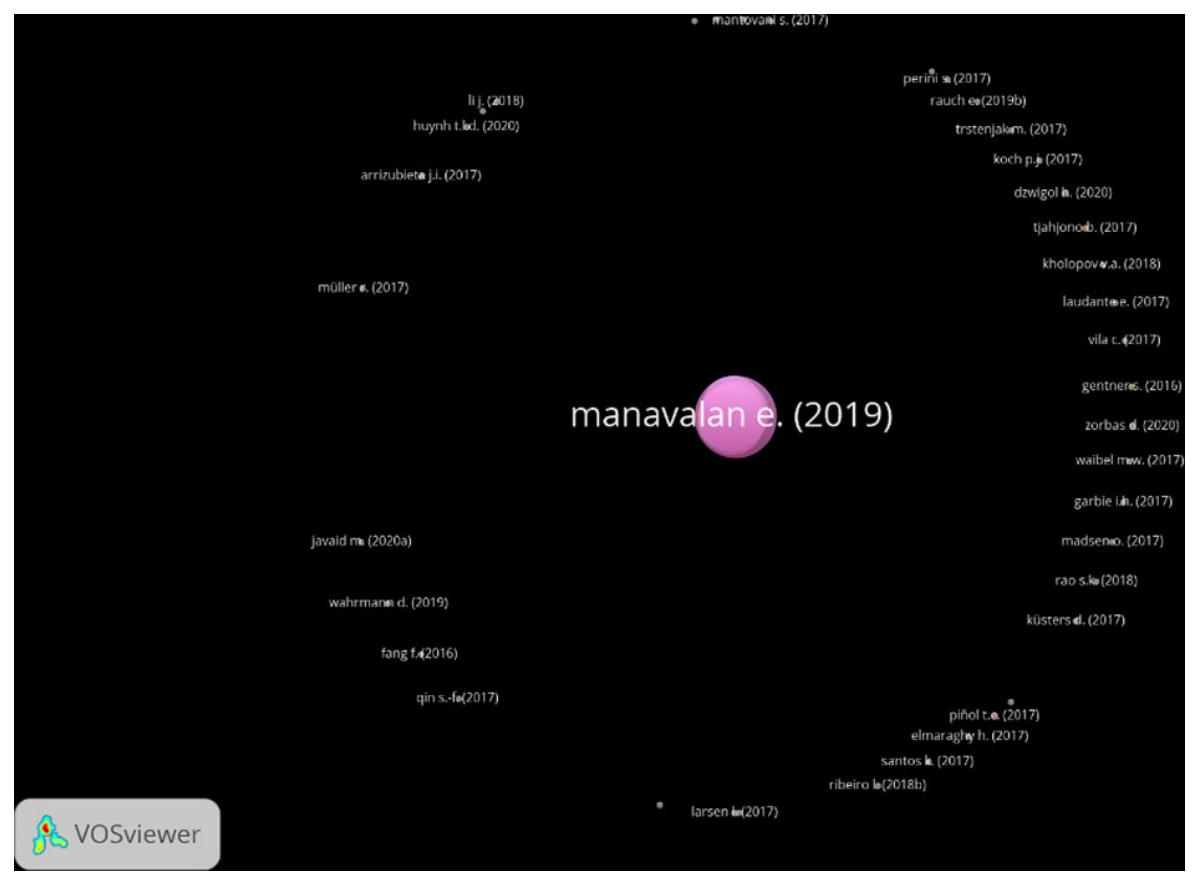

Fig. 9. Snapshot of bibliographic coupling (documents) based on TLS (unconnected documents)

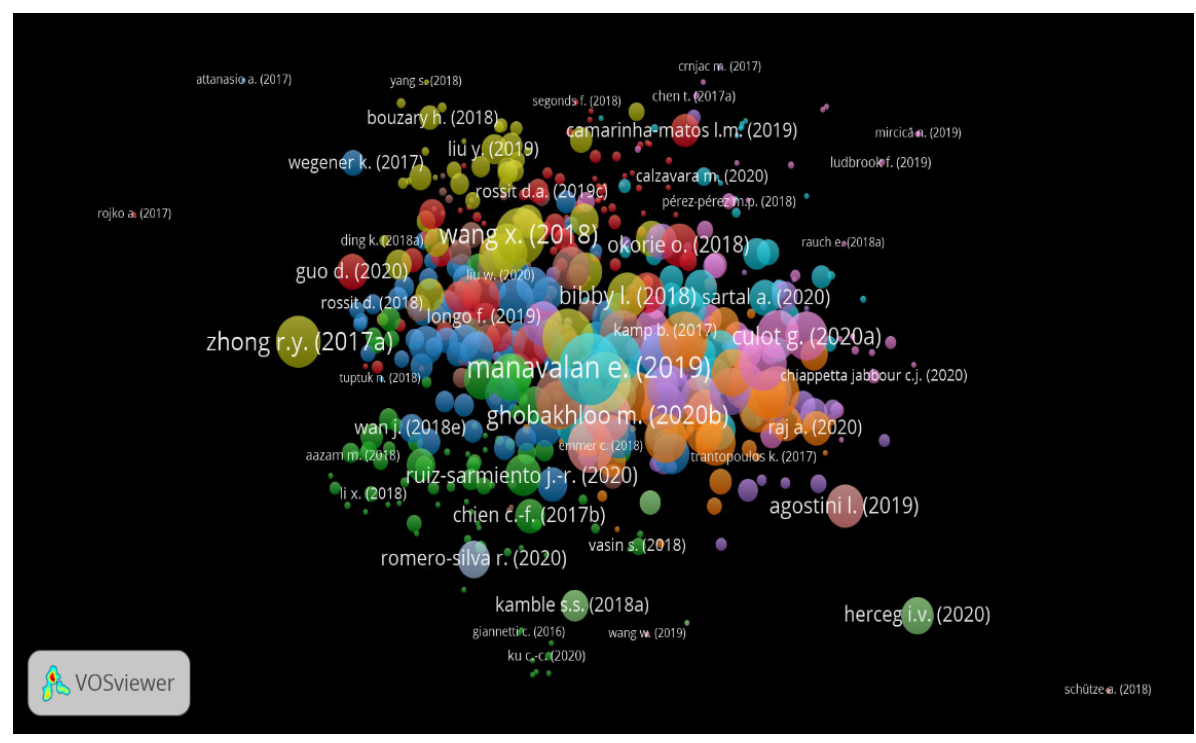

Fig. 10. Snapshot of bibliographic coupling (documents) based on TLS (connected documents) 


\section{Conclusion}

A detailed bibliometric analysis was conducted in this paper in the emergent field "Industry 4.0". The research patterns and development in this field were discovered with the help of bibliometric analysis. The findings of this study lead us to the conclusion that scientific publications in the field of Industry 4.0 are rapidly increasing, and this trend is expected to continue in the future due to the growing interest of academics and practitioners, as well as the fact that Industry 4.0 is a pressing need in a world where technology has taken over the world. Italy, the United States, and China are the most active countries in the field of Industry 4.0, with the most research publications. South China University of Technology (China), Università Degli Studi di Napoli Federico II (Italy), and Free University of Bozen-Bolzano (Italy) have been identified as the most productive institutions. Wan, J., Li, D., Rauch, E. were found to be the most productive authors with 18,17 and 13 publications respectively. Industry 4.0 is primarily focused on the fields of engineering and computer science. The top three journals contributing to the field were discovered to be Sustainability Switzerland, International Journal of Advanced Manufacturing Technology, and Applied Sciences Switzerland.

Our research findings are consistent with the previous researchers [2], [17] that in terms of the most commonly studied keywords, Internet of Things, Cyber-Physical Systems, Smart Manufacturing, Smart Factories, Big Data, Digitalisation, Sustainable Manufacturing, Additive Manufacturing, Digital Twins, Machine Learning, Artificial Intelligence, and Cloud Computing are the few which were examined through the visualization of the most common keywords in VOs viewer. Hence, it can be concluded that Industry 4.0 is an emerging research field, providing a gateway for further research, allowing the knowledge generated to be transferred further to assist and encourage novel research in the scientific community.

\section{$5 \quad$ Limitations and future directions}

The study's first limitation is that it has used just one database to select the previous literature. Although Scopus is regarded as a comprehensive database with extensive coverage of articles, it is possible to find additional journal articles by searching other databases such as Web of Science, Google Scholar, and others. Future studies could combine the articles from different database and conduct the review. Future studies could also compare the results from different databases. Another limitation is that more analysis, including additional bibliometric tools, could be done. Co-citation analysis, page rank analysis, and data clustering are just a few examples of these tools. Furthermore, we investigated design, human factors, artificial neural networks, critical success factors, data science, semantic web, anomaly detection, customization, human-robot collaboration, $5 \mathrm{~g}$, business process management, neural networks, remanufacturing, decision making, quality, skills, decisional DNA, emerging economies, collaborative manufacturing, and process mining are some emerging areas, and researchers could investigate these topics in-depth concerning Industry 4.0 in their future research activities. This study provides insights and prospects for future research on the issues on which researchers, universities, businesses, associations, politicians and technology 
providers need to invest effort in ensuring a smooth transition to the Fourth Industrial Revolution in real-time. This paper gives insights and opportunities for future research into the challenges that researchers, academic institutions and business organisations, technical suppliers and governments institutions must make to ensure that the fourth industrial revolution becomes a smooth transition in real-time.

\section{References}

[1] K. Zhou, T. Liu, and L. Zhou, "Industry 4.0: Towards future industrial opportunities and challenges," 2015, doi: https://doi.org/10.1109/FSKD.2015.7382284

[2] P. K. Muhuri, A. K. Shukla, and A. Abraham, "Industry 4.0: A bibliometric analysis and detailed overview," Eng. Appl. Artif. Intell., vol. 78, no. November 2017, pp. 218-235, 2019, doi: https://doi.org/10.1016/j.engappai.2018.11.007

[3] B. zena Gajdzik, S. Grabowska, S. Saniuk, and T. Wieczorek, "Sustainable development and industry 4.0: A bibliometric analysis identifying key scientific problems of the sustainable industry 4.0," Energies, vol. 13, no. 6, 2020, doi: https://doi.org/10.3390/en13164254

[4] I. Mustapha, N. T. Van, M. Shahverdi, M. I. Qureshi, and N. Khan, "Effectiveness of Digital Technology in Education During COVID-19 Pandemic. A Bibliometric Analysis," Int. J. Interact. Mob. Technol., vol. 15, no. 8, pp. 136-154, Apr. 2021, doi: https://doi.org/ 10.3991/ijim.v15i08.20415

[5] H. K. W. Wahlster and J. Helbig, "Umsetzungsempfehlungen für das Zukunftsprojekt Industrie 4.0: Abschlussbericht des Arbeitskreises Industrie 4.0," 2013.

[6] G. Beier, A. Ullrich, S. Niehoff, M. Reißig, and M. Habich, "Industry 4.0: How it is defined from a sociotechnical perspective and how much sustainability it includes A literature review," Journal of Cleaner Production. 2020, doi: https://doi.org/10.1016/ j.jclepro. 2020.120856

[7] S. Niehoff and G. Beier, "Industrie 4.0 and a sustainable development: a short study on the perception and expectations of experts in Germany," Int. J. Innov. Sustain. Dev., 2018, doi: https://doi.org/10.1504/IJISD.2018.091543

[8] H. S. Birkel, J. W. Veile, J. M. Müller, E. Hartmann, and K. I. Voigt, "Development of a risk framework for Industry 4.0 in the context of sustainability for established manufacturers," Sustain., 2019, doi: https://doi.org/10.3390/su11020384

[9] H. Kagermann, W.-D. Lukas, and W. Wahlster, "Industrie 4.0: Mit dem Internet der Dinge auf dem Weg zur 4. industriellen Revolution," VDI Nachrichten, 2011.

[10] F. Strozzi, C. Colicchia, A. Creazza, and C. Noè, "Literature review on the 'smart factory' concept using bibliometric tools," International Journal of Production Research. 2017, doi: https://doi.org/10.1080/00207543.2017.1326643

[11] N. Khan, M. I. Qureshi, I. Mustapha, S. Irum, and R. N. Arshad, "A systematic literature review paper on online medical mobile applications in Malaysia," Int. J. online Biomed. Eng., vol. 16, no. 1, pp. 63-82, Jan. 2020, doi: https://doi.org/10.3991/ijoe.v16i01.12263

[12] H. Small, "Visualizing science by citation mapping," J. Am. Soc. Inf. Sci., 1999, doi: https://doi.org/10.1002/(SICI)1097-4571(1999)50:9<799::AID-ASI9>3.0.CO;2-G

[13] M. J. Cobo, A. G. López-Herrera, F. Herrera, and E. Herrera-Viedma, "A Note on the ITS topic evolution in the period 2000-2009 at T-ITS," IEEE Trans. Intell. Transp. Syst., 2012, doi: https://doi.org/10.1109/TITS.2011.2167968

[14] M. A. Martínez, M. J. Cobo, M. Herrera, and E. Herrera-Viedma, "Analyzing the Scientific Evolution of Social Work Using Science Mapping," Res. Soc. Work Pract., 2015, doi: https://doi.org/10.1177/1049731514522101 
[15] J. A. Moral-Munoz, M. Arroyo-Morales, E. Herrera-Viedma, and M. J. Cobo, “An Overview of Thematic Evolution of Physical Therapy Research Area From 1951 to 2013," Front. Res. Metrics Anal., 2018, doi: https://doi.org/10.3389/frma.2018.00013

[16] E. M. Murgado-Armenteros, M. Gutiérrez-Salcedo, F. J. Torres-Ruiz, and M. J. Cobo, "Analysing the conceptual evolution of qualitative marketing research through science mapping analysis," Scientometrics, 2015, doi: https://doi.org/10.1007/s11192-014-1443-Z

[17] J. Borregan-Alvarado, I. Alvarez-Meaza, E. Cilleruelo-Carrasco, and G. Garechana-Anacabe, "A bibliometric analysis in industry 4.0 and advanced manufacturing: What about the sustainable supply chain?," Sustain., vol. 12, no. 19, 2020, doi: https://doi.org/ $10.3390 /$ su12197840

[18] L. M. Kipper, L. B. Furstenau, D. Hoppe, R. Frozza, and S. Iepsen, "Scopus scientific mapping production in industry 4.0 (2011-2018): a bibliometric analysis," Int. J. Prod. Res., vol. 58, no. 6, pp. 1605-1627, 2020, doi: https://doi.org/10.1080/00207543.2019.1671625

[19] P. Ajdovec, R. Kovačič Batista, and M. Vidmar, "Corporate Strategy and Industry 4.0: Bibliometric Analysis on Factors of Modernization," Dyn. Relationships Manag. J., vol. 6, no. 2, pp. 47-59, 2017, doi: https://doi.org/10.17708/DRMJ.2017.v06n02a04

[20] B. Bigliardi, G. Casella, and E. Bottani, "Industry 4.0 in the logistics field: A bibliometric analysis," IET Collab. Intell. Manuf., vol. 3, no. 1, pp. 4-12, 2021, doi: https://doi.org/ $10.1049 / \mathrm{cim} 2.12015$

[21] Y. Liao, F. Deschamps, E. de F. R. Loures, and L. F. P. Ramos, "Past, present and future of Industry 4.0 - a systematic literature review and research agenda proposal," International Journal of Production Research. 2017, doi: https://doi.org/10.1080/00207543.2017.1308576

[22] M. Pagliosa, G. Tortorella, and J. C. E. Ferreira, "Industry 4.0 and Lean Manufacturing: A systematic literature review and future research directions," J. Manuf. Technol. Manag., vol. 32, no. 3, pp. 543-569, 2021, doi: https://doi.org/10.1108/JMTM-12-2018-0446

[23] N. J. Van Eck and L. Waltman, "VOSviewer Manual: Manual for VOSviewer version 1.6.7," Univeristeit Leiden, no. February, p. 51, 2018.

[24] G. K. Ozbag, M. Esen, and D. Esen, "Bibliometric Analysis of Studies on Social Innovation," Int. J. Contemp. Econ. Adm. Sci., vol. 9, no. 1, pp. 25-45, 2019, doi: https://doi.org/10.5281/ zenodo.3262221

[25] J. M. Khudzari, J. Kurian, B. Tartakovsky, and G. S. V. Raghavan, "Bibliometric analysis of global research trends on microbial fuel cells using Scopus database," Biochem. Eng. J., 2018, doi: https://doi.org/10.1016/j.bej.2018.05.002

[26] K. Chen, Y. Zhang, and X. Fu, "International research collaboration: An emerging domain of innovation studies?," Res. Policy, 2019, doi: https://doi.org/10.1016/j.respol.2018.08.005

[27] M. Callon, J. P. Courtial, W. A. Turner, and S. Bauin, "From translations to problematic networks: An introduction to co-word analysis," Soc. Sci. Inf., 1983, doi: https://doi.org/ $\underline{10.1177 / 053901883022002003}$

[28] N. Khan and M. I. Qureshi, "A systematic literature review on online medical services in Malaysia," Int. J. online Biomed. Eng., vol. 16, no. 6, pp. 107-118, 2020, doi: https://doi.org/ 10.3991/ijoe.v16i06.13573 


\section{Authors}

Huma Sikandar, Azman Hashim International Business School (AHIBS), Universiti Teknologi Malaysia (UTM), 81310, Johor Bahru, Johor, Malaysia. E-mail: huma.sikandar@gmail.com.

Yamunah Vaicondam, Faculty of Business, Accountancy, Communication and Hospitality Management, SEGi University, Malaysia. E-mail: yamunahvaicondam@, segi.edu.my.

Nohman Khan, The Association of Professional Researchers \& Academicians (APRA), UK. E-mail: info@theapra.org.

Muhammad Imran Qureshi, Faculty of Technology Management and Technopreneurship, Universiti Teknikal Malaysia Melaka, Malaysia. E-mail: qureshi@utem.edu.my.

Abrar Ullah, Department of Management Sciences, University of Swabi, Pakistan. E-mail: abrar.ullah@uoswabi.edu.pk.

Article submitted 2021-07-15. Resubmitted 2021-08-25. Final acceptance 2021-08-26. Final version published as submitted by the authors. 